\title{
A comparison of three methods of Nitrogen analysis for feedstuffs
}

\author{
D. L. Figenschou ${ }^{\#}$, J. P. Marais and M. de Figueiredo \\ KwaZulu-Natal Department of Agriculture and Environmental Affairs, P. Bag X9059, Pietermaritzburg, 3201, South Africa. \\ \# e-mail: David.Figenschou@dae.kzntl.gov.za
}

\section{Introduction}

The Kjeldahl method for determining crude protein is very widely used for analysis of feed samples. However, it has its drawbacks and hence new techniques which are without some of the disadvantages are considered desirable. One such modification was developed by Hach et al. (1987). This promising technique was tested on a number of samples which were also analyzed by a more conventional Kjeldahl method, and by a Dumas method type analyzer and the results were compared.

\section{Material and Methods}

The conventional technique as routinely carried out in the Cedara feed analysis laboratory, consists of a digestion carried out in digestion tubes using $25 \mathrm{ml}$ of concentrated sulphuric acid and two commercial copper/titanium catalyst tablets. The Hach technique utilizes $5 \mathrm{ml}$ of concentrated sulphuric acid and 10-15ml of hydrogen peroxide delivered into the digest via a capillary funnel. After digestion the samples were diluted to 250 $\mathrm{ml}$ with deionized water and then read on an auto-analyzer (Technicon, Tarrytown, Pennsylvania, USA) using a Berthelot reaction (salicylate-hypochlorite) method. Samples were also analysed on a Leco CNS Analyzer (Leco CNS-2000, St Joseph, Michigan, USA) which is based on the Dumas dry combustion technique.

\section{Results}

The crude protein $(\mathrm{CP})$ content of samples digested by the two Kjeldahl type methods, and by the Dumas method analyzer are compared in Table 1.

Table 1 Crude protein as determined by modified and conventional techniques

\begin{tabular}{lccc}
\hline Sample Material & $\begin{array}{c}\text { \%CP } \\
\text { Conventional } \\
\text { Kjeldahl }\end{array}$ & $\begin{array}{c}\text { \%CP } \\
\text { Modified Kjeldahl }\end{array}$ & $\begin{array}{c}\text { \%CP } \\
\text { Leco (Dumas) }\end{array}$ \\
\hline Mushroom Compost & 12.81 & 13.19 & 13.19 \\
Lucerne & 16.92 & 16.31 & 16.13 \\
Citrus Pulp & 5.35 & 4.57 & 5.19 \\
Broken Beans & 20.29 & 21.01 & 20.81 \\
Clover & 30.34 & 28.57 & 29.81 \\
Soya & 46.27 & 47.88 & 48.94 \\
Eragrostis Hay & 6.21 & 5.51 & 6.56 \\
Sunflower Oil Cake & 44.95 & 45.44 & 46.69 \\
Fish & 73.61 & 73.46 & 69.63 \\
Mean & 28.53 & 28.44 & 28.56 \\
\hline
\end{tabular}

${ }^{1}$ Leco CNS-2000, St Joseph, Michigan, USA

\section{Conclusion}

Although only single replicate analyses were performed, the following preliminary conclusions may be drawn: the modified digestion technique gives results comparable to the conventional procedure and the Leco CNS analyzer. Advantages include the use of less sulphuric acid, shorter digestion times and easier fume control.

\section{References}

Hach, C.C., Bowden, B.K., Kopelove, A.B., and Brayton, S.V., 1987. More powerful peroxide Kjeldahl digestion method. J. Assoc. Off. Anal. Chem. 70, 783-787. 